\title{
ADSORPTION BEHAVIOR OF PROTEINS ON Mg(II)-DOPED CALCIUM HYDROXYAPATITE PARTICLES AT VARIOUS Mg(II) CONTENTS
}

\author{
Kazuhiko Kandori*, Yuya Hasegawa and Tomoki Kashiwara \\ (*Corresponding author: kandori@cc.osaka-kyoiku.ac.jp)
}

School of Chemistry, Osaka University of Education, 4-698-1Asahigaoka, Kashiwara-shi,

Osaka 582-8582, Japan

Keywords: Mg-doped calcium hydroxyapatite, adsorption behavior of proteins

\begin{abstract}
In this study, fundamental experiments on the adsorption behavior of proteins on synthesized magnesium-doped calcium hydroxyapatite particles (MgHap) at various $\mathrm{Mg} /(\mathrm{Ca}+\mathrm{Mg})$ molar ratios (abbreviated as $\left.\mathrm{X}_{\mathrm{Mg}}: 0-0.3\right)$ were examined. Rod-like calcium hydroxyapatite particles, with a width of $24 \mathrm{~nm}$ and length of $180 \mathrm{~nm}$, were obtained in the absence of $\mathrm{Mg}^{2+}\left(\mathrm{X}_{\mathrm{Mg}}=0\right)$. With the increase in $\mathrm{X}_{\mathrm{Mg}}$ up to 0.10 , the width and length of MgHap particles decreased to $\sim 10 \mathrm{and} 50 \mathrm{~nm}$, respectively. Agglomerates of small thin particles were obtained at $X_{\mathrm{Mg}} \geq 0.15$. All of the synthesized particles exhibited single phase of calcium hydroxyapatite particles (CaHap). The $\mathrm{X}_{\mathrm{Mg}}$ values for the particles precipitated at $\mathrm{X}_{\mathrm{Mg}} \geq 0.04$ were less than those of the corresponding solutions. Hence, almost all of the MgHap particles are deficient in magnesium. We propose that to compensate for the cation deficiency, $\mathrm{PO}_{4}{ }^{3-}$ is incorporated as $\mathrm{HPO}_{4}{ }^{2-}$ and $\mathrm{H}_{2} \mathrm{PO}_{4}{ }^{-}$and thus decreases the particle negative charge. In addition, all of the adsorption isotherms of typical acidic and basic proteins such as bovine serum albumin (BSA) and lysozyme (LSZ) were compared. The isotherms obtained from a $1 \times 10^{-4} \mathrm{~mol} / \mathrm{dm}^{3} \mathrm{KCl}$ solution were of the Langmuirian type. The saturated amount of adsorbed BSA $\left(n_{S}^{B S A}\right)$ strongly depended on the particle length rather than on the $\mathrm{X}_{\mathrm{Mg}}$ value. At a particle length of greater than $150 \mathrm{~nm}, n_{S}^{B S A}$ values abruptly increased. This result strongly suggests that the effects of the $\mathbf{C}$ sites produced on the $a c$ and $b c$ faces are advantageous for BSA adsorption. In other words, the adsorption of BSA on MgHap particles was considerably dependent on the length at a critical value of greater than $150 \mathrm{~nm}$. However, the saturated amount of adsorbed LSZ $\left(n_{S}^{L S Z}\right)$ exhibited no remarkable variation with the particle length.
\end{abstract}

(Received Apr 15, 2019; Accepted May 8, 2019)

\section{INTRODUCTION}

Calcium hydroxyapatite $\left(\mathrm{Ca}_{10}\left(\mathrm{PO}_{4}\right)_{6}(\mathrm{OH})_{2}\right.$ or $\mathrm{CaHap})$ particles are the primary constituents of hard tissues in animal organisms. Synthetic CaHap is used in bone implant surgery ${ }^{1}$. In addition, CaHap, with a space group of $\mathrm{P}_{3} / \mathrm{m}$ and unit-cell parameters $\mathrm{a}=\mathrm{b}=$ $0.943 \mathrm{~nm}$ and $\mathrm{c}=0.688 \mathrm{~nm}$, exhibits two binding sites, viz. $\mathbf{C}$ and $\mathbf{P}$ sites, on the $a c$ or $b c$ and $a b$ particle surfaces, respectively. Thus, CaHap exhibits multiple-site binding characteristics for proteins ${ }^{2-4}$. Hence, CaHap is widely used as a column in high-performance liquid chromatography (HPLC) apparatuses with applications for the separation of various proteins ${ }^{2,5,6}$.

Meanwhile, the CaHap structure is extremely tolerant to ionic substitution; several studies have reported the occupation of the $\mathrm{Ca}$ sites by various divalent (Ca(II), $\mathrm{Mn}(\mathrm{II}), \mathrm{Mg}(\mathrm{II}), \mathrm{Sr}(\mathrm{II}), \mathrm{Cd}(\mathrm{II}), \mathrm{Pb}(\mathrm{II})$, and $\mathrm{Ba}(\mathrm{II}))^{7-14}$, as well as trivalent (Al(III), $\mathrm{Fe}(\mathrm{III})$ ) [15] and tetravalent (Ti(IV) $)^{16,17}$ cations. Not only cations but also anionic $\mathrm{PO}_{4}{ }^{3-}$ can be exchanged with anions such as $\mathrm{CO}_{3}{ }^{2-}, \mathrm{SO}_{3}{ }^{2-}, \mathrm{AsO}_{4}{ }^{3-}$, and $\mathrm{VO}_{4}{ }^{3-}$. In addition, $\mathrm{OH}^{-}$can be substituted with $\mathrm{F}^{-}$and $\mathrm{Cl}^{-18}$. Typically, such modification of the CaHap structure is carried out by the incorporation of certain chemical dopants via coprecipitation ${ }^{15}$. Current studies have focused on the search for dopants that would not cause a disadvantageous effect of lowering the biocompatibility of CaHap, but instead would improve the biological and chemical characteristics of these compounds. Manganese (Mn), among others, is an additive proposed for this purpose. The presence of $\mathrm{Mn}$ ions in the CaHap structure leads to changes in the biological and chemical properties of CaHap materials ${ }^{18,19}$. Previously, the adsorption behavior of BSA and LSZ on Mn(II)-doped CaHap (MnHap) with plate- and rod-like particle morphologies has been investigated by our group ${ }^{20}$. Our results revealed that the saturated amounts of adsorbed BSA $\left(n_{S}^{B S A}\right)$ increase with the $\mathrm{Mn} /(\mathrm{Ca}+\mathrm{Mn})$ atomic ratio $\left(\mathrm{X}_{\mathrm{Mn}}\right)$ of plate-like MnHap, while the saturated amounts of 
adsorbed LSZ $\left(n_{S}^{L S Z}\right)$ decrease. This result is explained by the fact that a large fraction of positively charged adsorption sites produced on the $a c$ and $b c$ faces ( $\mathbf{C}$ sites) of plate-shaped particles is advantageous for the adsorption of negatively charged BSA.

The effect of magnesium $(\mathrm{Mg})$ on bone growth is of interest for biological studies. Magnesium deficiency can delay osteogenesis by lowering the osteoblast activity, possibly leading to bone deformation and growth inhibition, e.g., osteoporosis $^{21}$. Mg(II)-doped CaHap (MgHap) particles have characteristic of bioapatite in tooth and bone tissues ${ }^{22}$. In addition, these characteristic effects resulting from trace $\mathrm{Mg}^{2+}$ are strongly correlated with the adsorption behavior of proteins on CaHap surfaces. Hence, it is crucial to disclose the adsorption properties of proteins on MgHap particles with various $\mathrm{Mg} /(\mathrm{Ca}+\mathrm{Mg})$ atomic ratios $\left(\mathrm{X}_{\mathrm{Mg}}\right)$, in addition to the different sizes obtained as a result of coprecipitation, through a series of fundamental investigations for examining the protein adsorption behavior. One of our researchers, Yasukawa, has produced MgHap particles by the addition of an $\mathrm{H}_{3} \mathrm{PO}_{4}$ solution into a mixed solution of $\mathrm{Mg}\left(\mathrm{NO}_{3}\right)_{2}$ and $\mathrm{Ca}(\mathrm{OH})_{2}$ without $\mathrm{pH}$ control and reported the surface structure and properties of these MgHap particles $^{10}$. However, she has not investigated on the adsorption studies of proteins. Hence, the aim of this study is to clarify the fundamental adsorption behavior of typical acidic and basic proteins on sufficiently characterized MgHap particles with various sizes and $\mathrm{X}_{\mathrm{Mg}}$ atomic ratios, which were produced by the new coprecipitation method with $\mathrm{pH}$ control. The results obtained herein may not only provide fundamental results for the protein-MgHap interaction but also aid investigations of the effects of trace $\mathrm{Mg}^{2+}$ in biological fields.

\section{EXPERIMENTAL}

\section{Materials and Methods}

MgHap particles were synthesized by coprecipitation, which was similar to that reported previously for producing rod-like MnHap particles ${ }^{20}$. First, $\mathrm{Ca}\left(\mathrm{NO}_{3}\right)_{2}(0.32-0.40 \mathrm{~mol})$ and $\mathrm{Mg}\left(\mathrm{NO}_{3}\right)_{2}(0-$ $0.08 \mathrm{~mol}$ ) were dissolved in $20 \mathrm{dm}^{3}$ of pure water (free from $\mathrm{CO}_{2}$ ) at $\mathrm{X}_{\mathrm{Mg}}$ values between 0 and 0.3 . The total amounts of both $\mathrm{Ca}$ and $\mathrm{Mg}$ in the solutions were maintained at $0.4 \mathrm{~mol}$. Second, $\mathrm{H}_{3} \mathrm{PO}_{4}(0.24$ mol) was added to the solution, and the solution $\mathrm{pH}$ was adjusted to 9.5 by the addition of a $15 \mathrm{M} \mathrm{NH}_{4} \mathrm{OH}$ solution. Third, the resulting suspension was aged in a Teflon-capped vessel at $100^{\circ} \mathrm{C}$ for $48 \mathrm{~h}$. The generated particles were filtered, thoroughly washed with $10 \mathrm{dm}^{3}$ of pure water, and finally dried at $60^{\circ} \mathrm{C}$ in an air oven for $24 \mathrm{~h}$. All of the reagent-grade chemicals supplied by Wako Chemical Co. were used without further purification. Pure water from Elix (Millipore) was used to prepare all solutions. Freshly purified water exhibited a conductivity of $\sim 0.06$ $\mu \mathrm{S} / \mathrm{cm}$.

\section{Characterization}

Transmission electron microscopy (TEM; JEOL JEM-2100), $\mathrm{N}_{2}$ and $\mathrm{H}_{2} \mathrm{O}$ adsorption, and X-ray diffraction (XRD; Rigaku Miniflex 600) measurements were carried out to determine the shape, specific surface area (SSA), and crystal phase of the obtained compounds. $\mathrm{N}_{2}$ adsorption isotherms were obtained at liquid- $\mathrm{N}_{2}$ temperatures by the ordinary automatic volumetric flow method using a Baratron diaphragm-type manometer with an attached mass flow meter that was constructed in-house. The degree of confidence for the SSA measured by this apparatus was within $2 \%$. In addition, adsorption isotherms of $\mathrm{H}_{2} \mathrm{O}$ at $25^{\circ} \mathrm{C}$ were determined using a gravimetric apparatus constructed in-house. Prior to these gas adsorption measurements, the samples were evacuated at $100^{\circ} \mathrm{C}$ for $2 \mathrm{~h}$. SSAs were obtained by fitting the Brunauer-Emett-Teller (BET) equation to these $\mathrm{N}_{2}$ and $\mathrm{H}_{2} \mathrm{O}$ adsorption isotherms, which were abbreviated as $\mathrm{S}_{\mathrm{N}}$ and $\mathrm{S}_{\mathrm{W}}$, respectively. XRD patterns were recorded using Ni-filtered $\mathrm{CuK} \alpha$ radiation $(40 \mathrm{kV}, 120 \mathrm{~mA})$. The concentrations of $\mathrm{Ca}, \mathrm{Mg}$, and $\mathrm{P}$ in CaHap and MgHap were estimated by inductively coupled plasma-atomic emission spectroscopy (ICP-AES; Hitachi Hightech SPS3520UV-S) within a precision of $2 \%$ after the samples were dissolved in the $\mathrm{HCl}$ solution.

\section{Protein Adsorption Measurements}

The adsorbed amounts of BSA and LSZ molecules on the particles were measured by the batch method used in our previous studies ${ }^{23-31}$, which were purchased from Sigma Co. (BSA: A-7030 and LSZ: L-6876). To prevent protein decomposition, this measurement was conducted at $15^{\circ} \mathrm{C}$ using a $1 \times 10^{-4}$ $\mathrm{mol} / \mathrm{dm}^{3} \mathrm{KCl}$ solution of the protein containing 100 $\mathrm{mg}$ of MgHap in $10 \mathrm{~cm}^{3}$ Nalgene polypropylene centrifuge tubes. The centrifuge tubes were gently rotated end-over-end at $15^{\circ} \mathrm{C}$ for $48 \mathrm{~h}$ in a thermostat. The concentrations of each protein in the supernatant after centrifugation during rotation were determined by HPLC with UV monitoring at $220 \mathrm{~nm}$ using a YMC-Pack $\mathrm{C}_{4}$-AP column. Precise HPLC measurements have been reported previously ${ }^{20}$. A majority of the HPLC experiments were carried out in triplicate. The experiments were reproducible within $2 \%$, indicative of an uncertainty of $2 \times 10^{-2}$ $\mathrm{mg} / \mathrm{m}^{2}$ for the adsorbed amounts of protein. In addition, the zeta potential (zp) of the protein-adsorbed particles was estimated using an electrophoresis apparatus (PEN KEM Model 501) within an accuracy of $2 \%$. The diameter of the plotted 
circles in adsorption isotherms presented in this study also expressed each standard deviation.

\section{RESULTS AND DISCUSSION}

\section{Properties of the particles}

Figure 1 shows the typical TEM images of the produced MgHap. Rod-like CaHap $\left(\mathrm{X}_{\mathrm{Mn}}=0\right)$ particles with a width of $24 \mathrm{~nm}$ and length of $180 \mathrm{~nm}$ were observed. The particle size was determined by counting greater than 300 particles in numerous TEM images that were captured for each system by using WinRoof 2015 software. With the increase in $X_{M g}$ up to 0.10 , the particle width and length decreased to ca. 10 and $50 \mathrm{~nm}$, respectively. As the particles produced at $\mathrm{X}_{\mathrm{Mg}} \geq 0.15$ were agglomerates of small thin particles, their particle sizes were not determined. Table 1 summarizes the sizes of the obtained particles. Figure 2 shows the XRD patterns of the synthesized particles: All of the particles exhibited single phase of CaHap (JCPDS 9-432), indicating that the incorporated $\mathrm{Mg}^{2+}$ does not inhibit the CaHap crystal structure due to its rod-like morphology; however, the degree of crystallinity decreased. Similar results have been reported previously ${ }^{32-34} . \mathrm{Mg}^{2+}$ inhibits the formation of CaHap, creating amorphous CaHap crystals and increasing their solubility. Table 1 also summarizes the SSA values estimated from adsorption measurements of $\mathrm{N}_{2}$ and $\mathrm{H}_{2} \mathrm{O}$ molecules, abbreviated as $S_{N}$ and $S_{w}$, respectively, in addition to the $S_{W} / S_{N}$ ratio. With the increase in the $X_{M g}$ values of the solution, the $S_{N}$ and $S_{w}$ values increased from 76 and 48 to 296 and $317 \mathrm{~m}^{2} / \mathrm{g}$, respectively. This result corresponds to the decrease in their particle size (Fig. 1). The obtained results were similar to those reported by Yasukawa et al. ${ }^{10}$. Figure 3 shows the lattice constants of the $a$ - and $c$-axes for the MgHap particles estimated from the XRD patterns. The $a$ - and $c$-axis lengths were almost constant $(\sim 0.9420$ and $0.6880 \mathrm{~nm}$, respectively) in the entire range of $\mathrm{X}_{\mathrm{Mg}}$, as has been reported previously for single-crystal $\mathrm{CaHap}^{8}$. However, Yasukawa et al. reported that $a$ - and $c$-axis lengths decreased with the increase in $\mathrm{X}_{\mathrm{Mg}}$, i.e., the incorporation of $\mathrm{Mg}^{2+}(0.072$ $\mathrm{nm})$, rather less than that for $\mathrm{Ca}^{2+}(0.100 \mathrm{~nm})^{35}$, into $\mathrm{Ca}(\mathrm{I})$ sites may lead to column disorder, leading to the destruction of the Hap structure ${ }^{10}$. This difference between the results reported by Yasukawa and those reported here is related to the difference in the solution $\mathrm{pH}$ in coprecipitation. As the solution $\mathrm{pH}$ was adjusted to 9.5 herein, the particle growth of MgHap in this study proceeded smoothly.

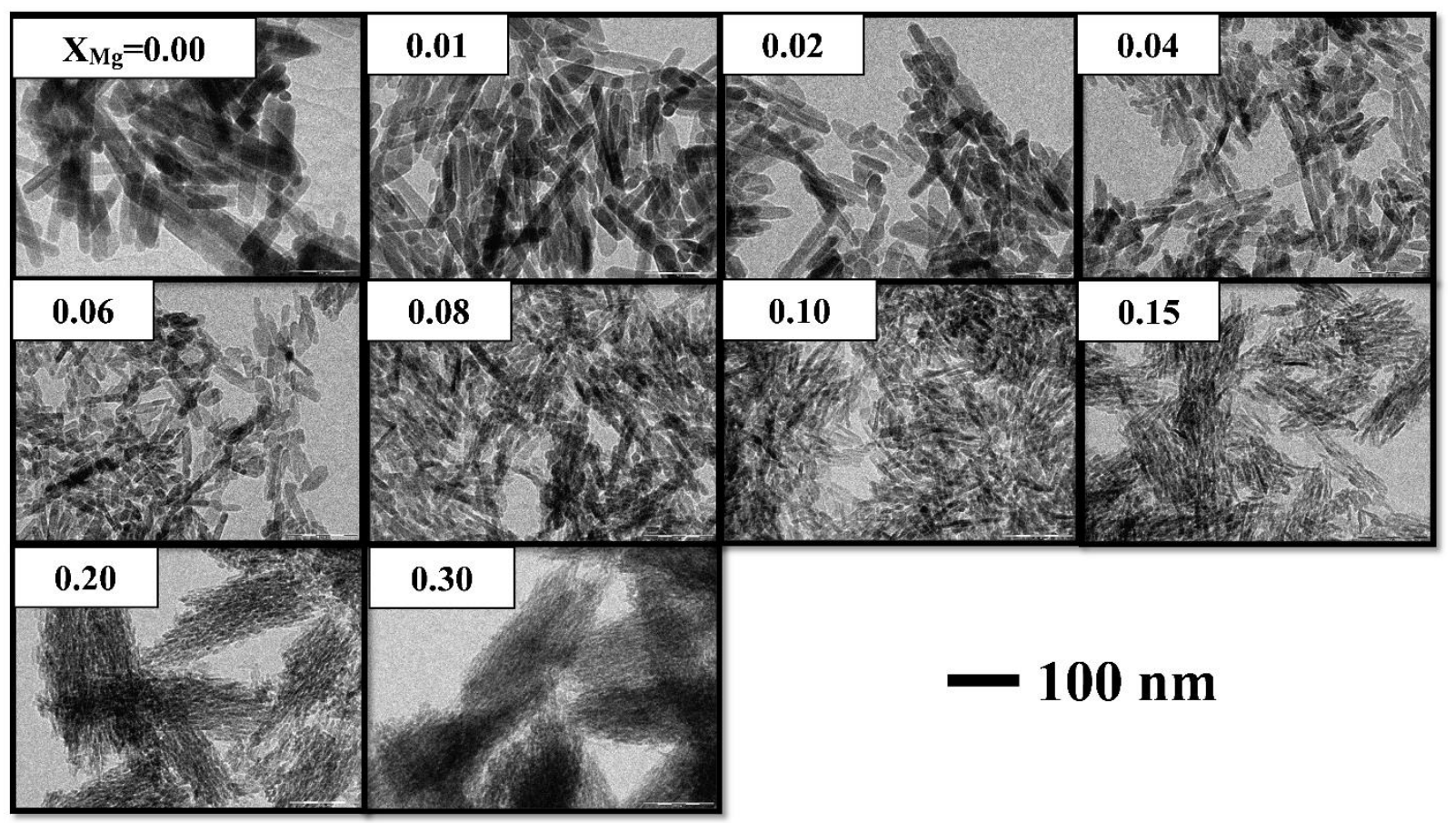

FIGURE 1 TEM images of the particles produced at various $\mathrm{X}_{\mathrm{Mg}}$ values. 
Table 1 Properties of CaHap and MgHap particles produced at various $\mathrm{X}_{\mathrm{Mg}}$ values.

\begin{tabular}{ccccccc}
\hline $\mathbf{X}_{\mathrm{mg}}{ }^{\text {a) }}$ & $\begin{array}{c}\text { Particle size[nm] } \\
\text { Width } \times \text { Length }\end{array}$ & $\begin{array}{c}\mathrm{S}_{\mathrm{N}} \\
{\left[\mathrm{m}^{2} / \mathrm{g}\right]}\end{array}$ & $\begin{array}{c}\mathrm{S}_{\mathrm{w}} \\
{\left[\mathrm{m}^{2} / \mathrm{g}\right]}\end{array}$ & $\mathrm{S}_{\mathrm{W}} / \mathrm{S}_{\mathrm{N}}$ & $\begin{array}{c}\mathrm{XMg}^{\mathrm{b})} \\
\text { in particle }\end{array}$ & $(\mathrm{Ca}+\mathrm{Mg}) / \mathrm{P}^{\mathrm{b})}$ \\
\hline 0.00 & $24 \times 180$ & 76 & 48 & 0.63 & 0.00 & 1.59 \\
0.01 & $25 \times 155$ & 79 & 55 & 0.70 & 0.01 & 1.55 \\
0.02 & $21 \times 149$ & 87 & 57 & 0.65 & 0.02 & 1.60 \\
0.04 & $19 \times 134$ & 114 & 79 & 0.70 & 0.03 & 1.62 \\
0.06 & $12 \times 97$ & 137 & 91 & 0.66 & 0.05 & 1.60 \\
0.08 & $13 \times 50$ & 157 & 122 & 0.78 & 0.06 & 1.54 \\
0.10 & $12 \times 53$ & 189 & 163 & 0.86 & 0.07 & 1.60 \\
0.15 & - & 191 & 228 & 1.18 & 0.12 & 1.45 \\
0.20 & - & 222 & 276 & 1.24 & 0.16 & 1.40 \\
0.30 & - & 296 & 317 & 1.07 & 0.21 & 1.47 \\
\hline
\end{tabular}

a) Atomic ratio of $\mathrm{Mg} /(\mathrm{Ca}+\mathrm{Mg})$ in solution.

b) Assayed by ICP-AES measurement.

Table 1 summarizes the $\mathrm{X}_{\mathrm{Mg}}$ values and $(\mathrm{Ca}+$ $\mathrm{Mn}) / \mathrm{P}$ ratios of the synthesized particles estimated by ICP-AES. The $\mathrm{X}_{\mathrm{Mg}}$ values produced from the assays of the particles precipitated at $\mathrm{X}_{\mathrm{Mn}} \leq 0.02$ were in fair agreement with those obtained for the solution although the $\mathrm{X}_{\mathrm{Mg}}$ values in particles were less than those of the corresponding solutions, indicative of the difficulty associated with the incorporation of $\mathrm{Mg}^{2+}$ into the CaHap crystal structure. This fact corresponds well with the XRD results. Bigi et al. have reported that the total concentration of $\mathrm{Mg}^{2+}$ in the solid phase is significantly greater than the amount of $\mathrm{Mg}^{2+}$ incorporated into the MgHap structure $^{36}$. They concluded that the excess $\mathrm{Mg}^{2+}$ is located in the amorphous phase and/or on the crystalline surface. MgHap particles were synthesized by the addition of $\mathrm{Ca}\left(\mathrm{NO}_{3}\right)_{2}$ and $\mathrm{Mg}\left(\mathrm{NO}_{3}\right)_{2}$ solutions to the $\mathrm{NH}_{4} \mathrm{H}_{2} \mathrm{PO}_{4}$ solution at neutral $\mathrm{pH}$ without aging, which could produce a high content of the amorphous phase in the precipitates.

Figure 4 shows the concentrations of calcium, magnesium, and phosphorus (i.e., $[\mathrm{Ca}],[\mathrm{Mg}]$, and $[\mathrm{P}]$, respectively) in the obtained MgHap particles. These values determined from the ICP-AES measurements were plotted as a function of $\mathrm{X}_{\mathrm{Mg}}$ in the solution. [Ca] and $[\mathrm{Mg}]$ linearly decreased (with a slope of -12.5) and increased (with a slope of +6.0), respectively, with an $\mathrm{X}_{\mathrm{Mg}}$ value of up to $\mathrm{X}_{\mathrm{Mg}}=0.2$. However, [P] was almost constant. This result reveals that only $50 \%$ of $\mathrm{Mg}^{2+}$ is exchanged with $\mathrm{Ca}^{2+}$ and that particles exhibit cation deficiency. This fact is further confirmed by the $(\mathrm{Ca}+\mathrm{Mg}) / \mathrm{P}$ values summarized in Table 1. All of these values were less than the theoretical value of 1.67. To compensate for the cation deficiency, $\mathrm{PO}_{4}{ }^{3-}$ is probably incorporated as $\mathrm{HPO}_{4}{ }^{2-}$ and $\mathrm{H}_{2} \mathrm{PO}_{4}{ }^{2-}$ to reduce the particle negative charge. In addition, the presence of $\mathrm{HPO}_{4}{ }^{2-}$ was identified by TG-DTA measurements (data not shown). The weight losses in $\mathrm{TG}$ and endothermic peaks, corresponding to the elimination of $\mathrm{H}_{2} \mathrm{O}$ molecules from the dehydration of $\mathrm{HPO}_{4}{ }^{2-}$, were observed at $700-900^{\circ} \mathrm{C}$.

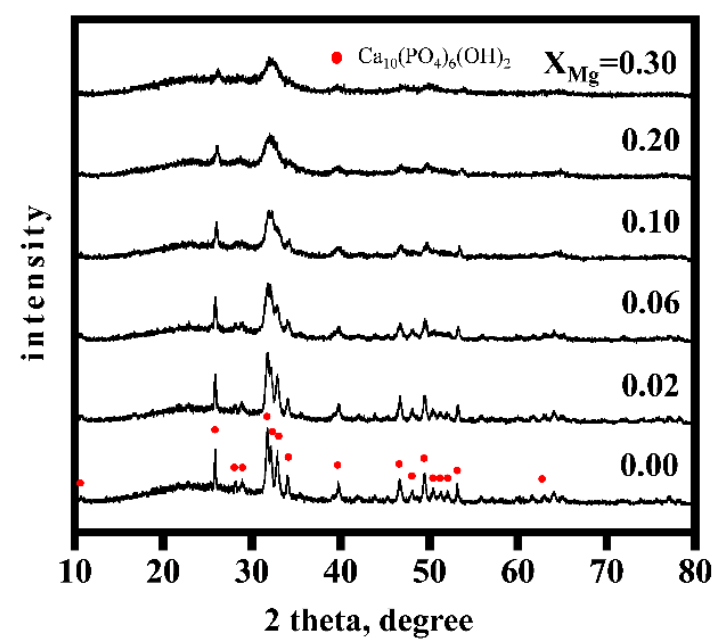

FIGURE 2 XRD patterns of the particles produced at various $X_{M g}$ values. 


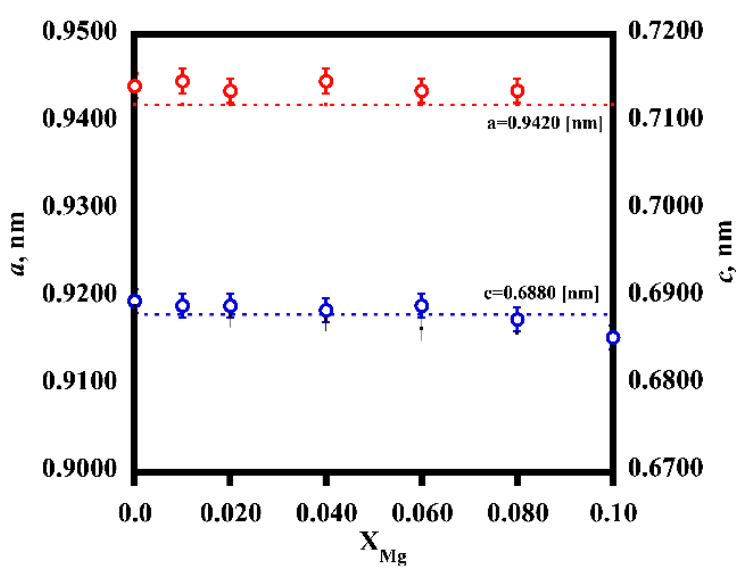

FIGURE 3 Changes in the lattice constants of $a$ and $c$-axes of the particles produced at various $\mathrm{X}_{\mathrm{Mg}}$ values.

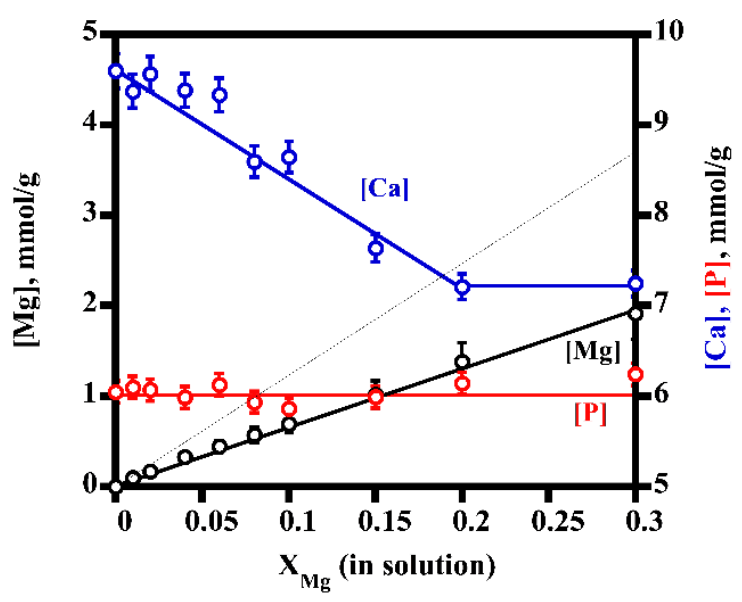

FIGURE 4 Changes in [Ca], $[\mathrm{Mg}]$ and $[\mathrm{P}]$ in the particles produced as a function of $\mathrm{X}_{\mathrm{Mg}}$ values. The black dot straight line reveals the $[\mathrm{Mg}]$ line when $\mathrm{Mg}(\mathrm{II})$ is completely exchanged with $\mathrm{Ca}(\mathrm{II})$.

\section{Adsorption Behavior of Proteins on MgHap Particles}

Figure 5 shows the adsorption isotherms of BSA on MgHap particles, in addition to their corresponding zp values. Here the MgHap particles with $\mathrm{X}_{\mathrm{Mg}} \leq 0.2$ were employed because MgHap particles produced at $\mathrm{X}_{\mathrm{Mg}}=0.3$ were considerably amorphous. All of the adsorption isotherms for BSA obtained from the $1 \times 10^{-4} \mathrm{~mol} / \mathrm{dm}^{3} \mathrm{KCl}$ solution were of the Langmuirian type, as well as the previously reported adsorption systems for CaHap and MnHap particles ${ }^{20,23-31}$. The saturated amount of adsorbed BSA $\left(n_{s}^{B S A}\right)$ on CaHap $\left(\mathrm{X}_{\mathrm{Mg}}=0\right)$ was 1.50 $\mathrm{mg} / \mathrm{m}^{2}$. The adsorption coverage of BSA $\left(\theta_{\mathrm{BSA}}\right)$ in this system, which is defined as the ratio of the experimental $n_{s}^{B S A}$ to its theoretical value, was 0.60 . The theoretical value used in the aforementioned calculation was estimated to be $2.52 \mathrm{mg} / \mathrm{m}^{2}$ by assuming the side-on adsorption of globular BSA molecules, which were prolate ellipsoids with dimensions of $14 \times 4 \mathrm{~nm}^{2}{ }^{37}$. As the solution $\mathrm{pH}$ of the system was $\sim 6$, the BSA molecules were negatively charged. Hence, the negative values obtained for the $\mathrm{zp}$ of this system increase with the amount of adsorbed BSA. However, a relationship between the saturated positive $\mathrm{zp}$ value and $\mathrm{X}_{\mathrm{Mg}}$ values, except for $\mathrm{X}_{\mathrm{Mg}}=0.10$ and 0.20 , which exhibited higher negative zp values, was not observed. Nevertheless, currently, there is no explanation for this result, and a detailed understanding of this result needs additional investigation.

Figure 6 shows the data obtained for the adsorption of LSZ. Langmuirian-type isotherms, as well as the BSA system in Fig. 5, can be recognized. The saturated amount of adsorbed LSZ ( $n_{s}^{L S Z}$ ) slightly decreased with the increase in $X_{\mathrm{Mg}}$, but we did not observe a large difference for the MgHap particles with $0.02 \leq \mathrm{X}_{\mathrm{Mg}} \leq 0.20$. All of these systems exhibited $n_{s}^{L S Z}$ values of $0.08-0.12 \mathrm{mg} / \mathrm{m}^{2}$. As LSZ is positively charged, LSZ molecules are preferentially adsorbed on negatively charged $\mathbf{P}$ sites exposed on the $a b$ particle surface. A relationship was not observed between $n_{S}^{L S Z}$ and $\mathrm{X}_{\mathrm{Mg}}$ values because the degree of reduction of the particle width was less than the particle length. A low fraction of $\mathbf{P}$ sites intrinsic to the rod-like particles was observed. Hence, the effect of $\mathbf{C}$ sites on the LSZ adsorption is regarded to be negligible. We observed positive $\mathrm{zp}$ values for these systems as LSZ molecules were positively charged under the experimental conditions. The saturated positive zp value for the CaHap $\left(\mathrm{X}_{\mathrm{Mg}}=\right.$ 0 ) system was the highest $(+10 \mathrm{mV})$, while the other systems exhibited considerably lower, but almost equal, values $(+4$ to $+6 \mathrm{mV})$. This decrease in the absolute value of the positive $\mathrm{zp}$ of the systems for $\mathrm{X}_{\mathrm{Mn}}=0.01-0.20$ is related to the shift in the slipping plane caused by the adsorption of the LSZ molecules $^{38}$.

Several studies have previously reported the driving forces for protein adsorption, including coulombic electrostatic interactions, van der Waals interactions (depending on the particle size), hydrophobic interactions, and structural rearrangement on adsorption (especially in the case of BSA $)^{39-50}$. As the difference in terms of the $S_{w} / S_{N}$ ratio was not observed for the surface hydrophobicity of the particles (Table 1), a discussion regarding the hydrophobic interactions of these systems can be omitted herein. The $n_{s}^{B S A}$ values for the MgHap particles were greater than those of $n_{S}^{L S Z}$. This result can be explained by the structural rearrangement of the soft protein BSA with a large molecular weight; the particles used herein exhibited a relatively large, flat surface (Fig. 1).

To describe the dependence of protein adsorption on the MgHap particle structure used for adsorption, the $n_{s}^{B S A}$ and $n_{s}^{L S Z}$ values were plotted as a function 
of the $\mathrm{X}_{\mathrm{Mg}}$ values of MgHap particles in Fig. 7(a). The $n_{S}^{B S A}$ and $n_{s}^{L S Z}$ values decreased up to $\mathrm{X}_{\mathrm{Mg}}=$ 0.04 and reached $\sim 0.45$ and $\sim 0.1 \mathrm{mg} / \mathrm{m}^{2}$, respectively. Although there was no large difference in the $(\mathrm{Ca}+\mathrm{Mg}) / \mathrm{P}$ values for the $\mathrm{MgHap}$ particles produced at $0.04 \leq \mathrm{X}_{\mathrm{Mg}} \leq 0.20$, the $(\mathrm{Ca}+\mathrm{Mg}) / \mathrm{P}$ values were in

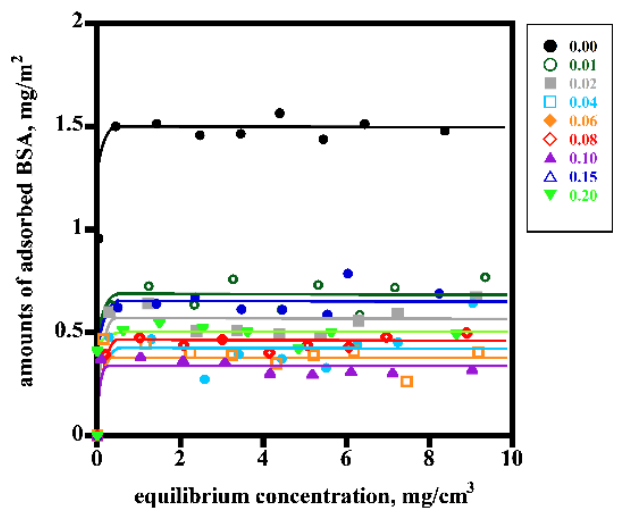

the range of 1.40-1.62. In addition, low amounts of $\mathrm{Mg}^{2+}$ were incorporated into the particles, i.e., the fraction of incorporated $\mathrm{Mg}^{2+}$ against $\mathrm{Ca}^{2+}$ was $\sim 0.5$ (Fig. 4). Hence, the reduction in the $n_{s}^{B S A}$ and $n_{s}^{L S Z}$ values cannot be attributed to the chemical composition of MgHap particles.

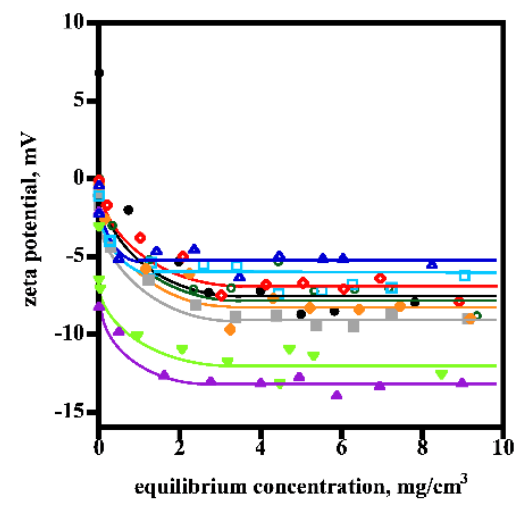

FIGURE 5 Adsorption isotherms of BSA on MgHap particles produced at various $\mathrm{X}_{\mathrm{Mg}}$ values and their zp values.
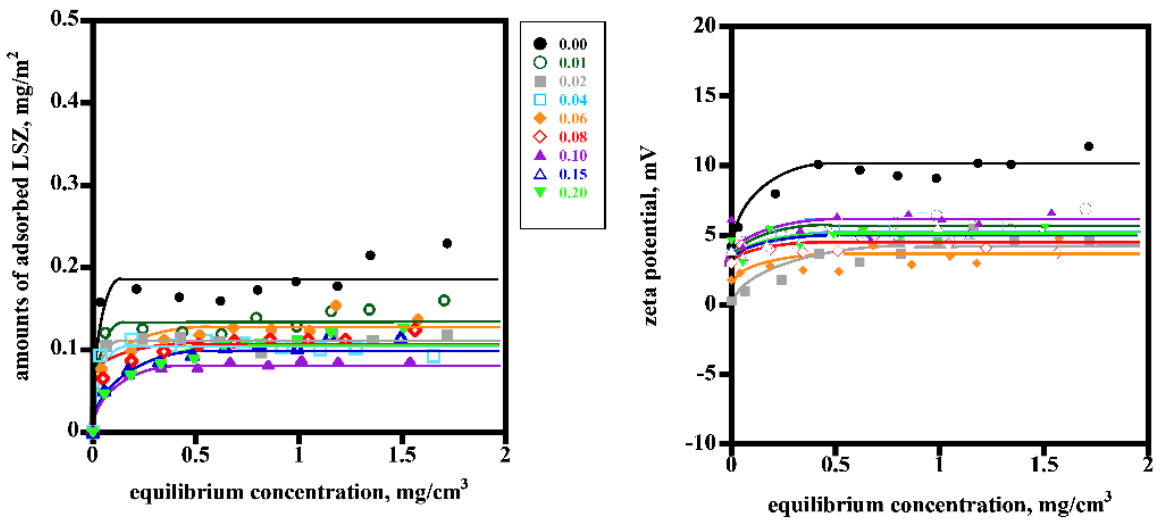

FIGURE 6 Adsorption isotherms of LSZ on MgHap particles produced at various $\mathrm{X}_{\mathrm{Mg}}$ values and their zp values.
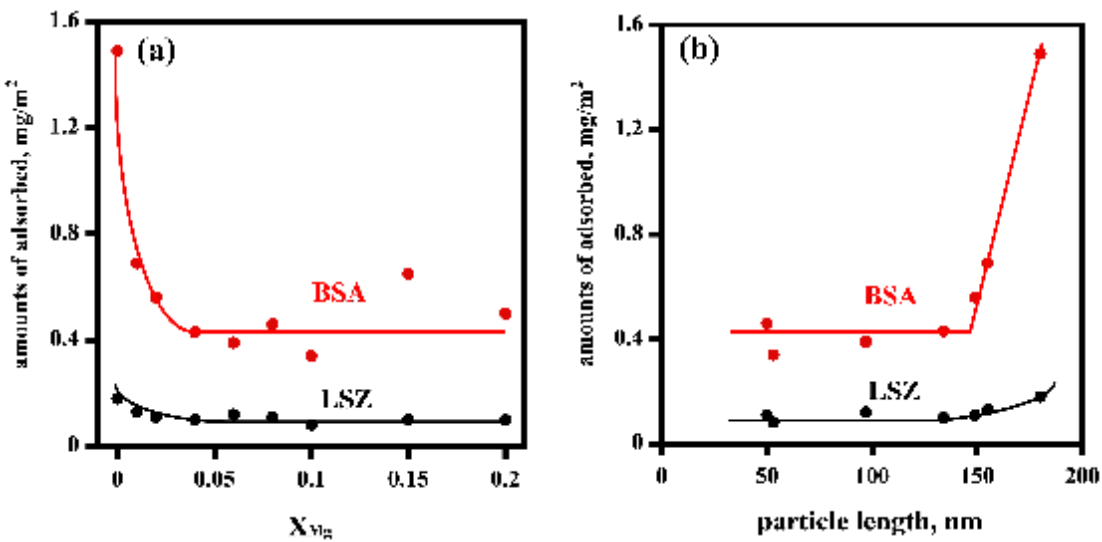

FIGURE 7 Saturated amounts of BSA and LSZ as a function of (a) $\mathrm{X}_{\mathrm{Mg}}$ and (b) particle length. 
Next, the alteration in particle morphology should be considered. To clarify this point, the $n_{s}^{B S A}$ and $n_{s}^{L S Z}$ values were further plotted as a function of the particle length of MgHap particles in Fig. 7(b). Notably, a critical point was clearly observed for $n_{s}^{B S A}$ (Fig. 7(b)). The $n_{s}^{B S A}$ values abruptly increased at a particle length of greater than $150 \mathrm{~nm}$. This result can be explained by the variation in length of these particles, i.e., there is an increase in the large fraction of positively charged C sites on the rod-like particles, which is advantageous for the adsorption of the negatively charged BSA at $\mathrm{pH} 6$. In other words, the adsorption of BSA dictates a MgHap particle length of greater than $150 \mathrm{~nm}$. In a previous study, the author has reported that the $n_{s}^{B S A}$ values are strongly dependent on the length of the CaHap particles between 60 and $5210 \mathrm{~nm}(0.06-5.21 \mu \mathrm{m})^{28}$. However, CaHap particles with a length of greater than $60 \mathrm{~nm}$ exhibit $n_{S}^{B S A}$ values of $1.0-1.8 \mathrm{mg} / \mathrm{m}^{2}$, and we did not observe a critical point. This result leads the conclusion that particle length is among the most important properties on the adsorption of BSA onto MgHap particles, though the detailed mechanism is left to subsequent papers.

In this section, the adsorption behavior of proteins on rod-like MgHap particles with various $\mathrm{X}_{\mathrm{Mg}}$ values was elucidated. The obtained results not only provided fundamental results for the proteinMgHap interactions, but also extended to the investigation of the effects of trace $\mathrm{Mg}^{2+}$ in biological fields. A critical particle length $(150 \mathrm{~nm})$ for the adsorption of BSA was noted. The valuable results obtained herein reveal that the adsorption of BSA leads to MgHap particles with a length of greater than $150 \mathrm{~nm}$.

\section{CONCLUSIONS}

Fundamental experiments on the adsorption behavior of proteins on MgHap synthesized at various $\mathrm{Mg}(\mathrm{II})$ contents $\left(\mathrm{X}_{\mathrm{Mn}}=0-0.3\right)$ were carried out. Rod-like CaHap particles with a width of 24 $\mathrm{nm}$ and a length of $180 \mathrm{~nm}$ were obtained. With the increase in $\mathrm{X}_{\mathrm{Mg}}$ up to 0.10 , the particle width and length decreased to $\sim 10$ and $50 \mathrm{~nm}$, respectively. All of the synthesized particles afforded peaks characteristic of CaHap, but almost all of the MgHap particles were deficient in magnesium. All of the adsorption isotherms of BSA and LSZ obtained from a $1 \times 10^{-4} \mathrm{~mol} / \mathrm{dm}^{3} \mathrm{KCl}$ solution were of the Langmuir type. The saturated amount of adsorbed BSA $\left(n_{S}^{B S A}\right)$ strongly depended on the particle length rather than the $\mathrm{X}_{\mathrm{Mg}}$ value. The $n_{s}^{B S A}$ values abruptly increased with a particle length of greater than $150 \mathrm{~nm}$. In other words, the BSA adsorption leads to a MgHap particle length of greater than $150 \mathrm{~nm}$. However, the saturated amount of adsorbed LSZ $\left(n_{s}^{L S Z}\right)$ did not exhibit any remarkable variation with the particle length. The results obtained herein can possibly aid investigations of the effects of trace $\mathrm{Mg}^{2+}$ ions in biological fields.

\section{REFERENCES}

1. C. Van Blitterswijk (Ed), Tissue Engineering Academic Press Series in Biomedical Engineering, Elsevier, Amsterdam, Chapter 8(2008).

2. T. Kawasaki, S. Takahashi, K. Ikeda, Eur. J. Biochem. 152, 361(1985).

3. T. Kawasaki, M. Niikura, S. Takahashi, W. Kobayashi, Biochem. Int. 13, 969(1986).

4. T. Kawasaki, K. Ikeda, S.Takahashi, Y. Kuboki, Eur. J. Biochem. 155, 249(1986).

5. A. Tiselius, S. Hjertén, Ö. Levin, Acrh. Biochem. Phys. 65, 132 (1956).

6. J. M. Thomann, M. J. Mura, M. S. Behr, J. D. Aptel, A. Schmitt, E. F. Bres, E. J. C. Voegel, Colloids Surf. 40, 293(1989).

7. P. W. Brown, B. Constants, Hydroxyapatite and Related Materials, CRC Press, Inc., Boca Raton, 1994, p.3.

8. Elliott, J. C. Structure and Chemistry of the Apatites and Other Calcium Orthophosphates, Elsevier, Amsterdam, 1994.

9. R. Z. LeGeros, Calcium Phosphates in Oral Biology and Medicine, Karger, Basle, 1991.

10. A. Yasukawa, S. Ouchi, K. Kandori, T. Ishikawa, J. Mater. Chem. 6, 1401(1996).

11. T. Ishikawa, H. Saito, A. Yasukawa, K. Kandori, J. Chem. Soc. Faraday Trans. 89, 3821(1993).

12. A. Yasukawa, M. Higashijima, K. Kandori, T. Ishikawa, Colloids and Surfaces A, 268, 111(2005). 13. A. Yasukawa, K. Kamiuchi, T. Yokoyama, K. Kandori, T. Ishikawa, J. Solid State Chem. 163, 27(2002).

14. A. Yasukawa, E. Ueda, K. Kandori, T. Ishikawa, J. Colloids and Interface Surf. 288, 468(2005).

15. M. Wakamura, K. Kandori, T. Ishikawa, Colloids Surf., A. 164, 297(2000).

16. M. Wakamura, K. Hashimoto, T. Watanabe, Langmuir, 19, 3428(2003).

17. N. Yoshida, M. Takeuchi, T. Okura, H. Monma, M. Wakamura, H. Ohsaki, T. Watanabe, Thin Solid Films, 502, 108(2006).

18. L. Medvecký, R. Štulajterová, L. Parilák, J. Trpčevská, J. Ďurišin, S. M. Barinov, Colloids Surf., A. 281, 221(2006).

19. S. Ramesh, S. Y. Tan, C. L. Peralta and W. D. Teng, Sci. Tech. of Adv. Mater., 8, 257(2007).

20. K. Kandori, R. Murata, Y. Yamaguchi, A. Yoshioka, Colloids and Surfaces, B. 167, 36(2018).

21. T. J. Webster, E. A. Mass-Schlueter, J. L. Smith, E. B. Slamovich, Biomaterials, 25, 2111(2004). 
22. I. D. B. Featherstone, I Mayer, F. C. M. Driessens, R. M. H. Verbeeck and H. J. M. Heijligers, Calcif. Tissue Int., 35, 169(1983).

23. K. Kandori, S. Sawai, Y. Yamamoto, H. Saito, T. Ishikawa, Colloids Surf., 68, 283(1992).

24. K. Kandori, Y. Yamamoto, H. Saito, T. Ishikawa, Colloids Surf., A, 80, 287(1993).

25. K. Kandori, M. Saito, H. Saito, A. Yasukawa, T. Ishikawa, Colloids Surf., A. 94, 225(1995).

26. K. Kandori, M. Saito, T. Takebe, A. Yasukawa, T. Ishikawa, J. Colloid Interface Sci. 174, 124(1995).

27. K. Kandori, T. Shimizu, A. Yasukawa, T. Ishikawa, Colloids Surf., B. 5, 81(1995).

28. K. Kandori, A. Fudo, T. Ishikawa, Phys. Chem. Chem. Phys. 2, 2015(2002).

29. K. Kandori, A. Masunari, T. Ishikawa, Calcif. Tissue Int. 76, 194(2005).

30. K. Kandori, K. Murata, T. Ishikawa, Langmuir, 23, 2064(2007).

31. K. Kandori, S. Mizumoto, S. Toshima, M. Fukusumi, Y. Morisada, J. Phys. Chem. B. 113, 11016(2009).

32. P. Cheng, J. J. Grabher, R. Z. LeGeros, Magnesium, 7, 123(1988).

33. J. W. L. Wilson, P. G. Werness, L. H. Smith, J. Urol., 134, 1255(1985).

34. A. L. Boskey, A. S. Posner, Meter. Res. Bull., 9, 907(1974).

35. R. D. Shannon, Acta. Cryst. A 32, 751(1976).

36. A. Bigi, G. Falini, E. Foresti, M. Gazzao, A. Ripamonti, N. Roveri, Acta Cryst. B, 52, 87(1996).
37. P. G. Squire, P. Moser, C. T. O'Konski, Biochemistry, 7, 4261(1968).

38. D. J. Meier, J. Phys. Chem., 71, 861(1967).

39. W. Norde, Advances in Colloid and Interface Science, 25, 267(1986).

40. C. A. Haynes, W. Norde, Colloids and Surfaces $B, 2,517(1994)$.

41. W. Norde, Cells and Materials, 5, 97(1995).

42. W. Norde, in "Physical chemistry of biological interfaces" A. Baszkin, W. Norde, eds., Marcel Dekker, New York, 2000, 115.

43. J. J. Ramsden Quart Rev Biophys. 27, 41(1993). 44. P. Schaaf, P. Dejardin, Colloids Surfaces, 31, 89(1988).

45. P. Schaaf, P. Dejardin, A. Johner, A. Schmit, Langmuir, 3, 1128(1987).

46. M. Malmsten, "Biopolymers at Interfaces, Revised and Expanded", M. Malmsten (Ed.),

Surfactant Science Series, Volume 110, Marcel Dekker, New York, 2003.

47. M. Malmsten, J. Colloid Interface Sci.166, 333(1994).

48. M. Malmsten, B. Lassen, J. Colloid Interface Sci. 166, 490 (1994).

49. M. Malmsten, B. Lassen, ACS Symp. Ser., Eds. T. A. Horbett, J. L. Brash, American Chemical Society, Washington DC, 1995.

50. M. Malmsten, in "Protein Architecture: Interfacing Molecular Assemblies and Immobilization Biotechnology", Eds. Y. Lvov, H. Möhwald, Marcel Dekker, Inc., New York, 1999. 